\title{
A low-protein, high carbohydrate diet induces increase in serum adiponectin and preserves glucose homeostasis in rats
}

\author{
PATRÍCIA CEOLIN ${ }^{1}$, SUÉLEM A. DE FRANÇA ${ }^{1}$, MENDALLI FROELICH ${ }^{1}$, MAÍSA P. DOS \\ SANTOS ${ }^{1}$, MAYARA P. PEREIRA ${ }^{1}$, THAÍS S. QUEIROZ ${ }^{1}$, FLÁVIA H.S. DA SILVA ${ }^{1}$, PATRÍCIA C. \\ LISBOA $^{2}$, CLAUDIA M.B. ANDRADE ${ }^{1}$, AMANDA M. BAVIERA ${ }^{3}$ and NAIR H. KAWASHITA ${ }^{1}$ \\ ${ }^{1}$ Departamento de Química, Universidade Federal de Mato Grosso, Av. Fernando \\ Correa da Costa, 2367, 78060-900 Cuiabá, MT, Brazil \\ ${ }^{2}$ Departamento de Ciências Fisiológicas, Instituto de Biologia Alcantara Gomes, Universidade \\ do Estado do Rio de Janeiro, $5^{\circ}$ andar, 20551-030 Rio de Janeiro, RJ, Brazil \\ ${ }^{3}$ Departamento de Análises Clínicas Júlio de Mesquita Filho, Rua Expedicionários \\ do Brasil, 1621, 14801-902 Araraquara, SP, Brazil \\ Manuscript received on May 8, 2018; accepted for publication on August 20, 2018
}

\begin{abstract}
How to cite: CEOLIN P ET AL. 2019. A low-protein, high carbohydrate diet induces increase in serum adiponectin and preserves glucose homeostasis in rats. An Acad Bras Cienc 91: e20180452. DOI 10.1590/00013765201920180452 .
\end{abstract}

\begin{abstract}
The aim of this study was investigate the effects of a low-protein, high-carbohydrate (LPHC) diet introduced to rats soon after weaning. The animals were distributed in the following groups: $\mathrm{LPHC}_{45}$ : fed an LPHC diet (6\%-protein, 74\%-carbohydrate) for 45 days; $\mathrm{C}_{45}$ : fed a control (C) diet (17\%-protein, 63\%-carbohydrate) for 45 days; R (Reverse): fed with LPHC for 15 days followed by C diet for 30 days. The $\mathrm{LPHC}_{45}$ group showed alterations in the energetic balance with an increase in brown adipose tissue, and in glucose tolerance, and lower final body weight, muscle mass and total protein in blood when compared with $\mathrm{C}_{45}$ group. The HOMA-IR index was similar between $\mathrm{LPHC}_{45}$ and $\mathrm{C}_{45}$ groups, but this parameter was lower in $\mathrm{LPHC}_{45}$ compared with $\mathrm{R}$ groups. Serum adiponectin was higher in $\mathrm{LPHC}_{45}$ group than $\mathrm{C}_{45}$ and $\mathrm{R}$ groups. The $\mathrm{R}$ group presented higher fed insulin than $\mathrm{C}_{45}$ and $\mathrm{LPHC}_{45}$ and higher $\mathrm{T} 4$ compared with $\mathrm{C}_{45}$ group. Total cholesterol in $\mathrm{R}$ group was higher when compared with $\mathrm{LPHC}_{45}$ group. Thus, the data show that the change of the diet LPHC for a balanced diet led to different metabolic evolution and suggest that the different response can be due to different levels of adiponectin.
\end{abstract}

Key words: low-protein, high-carbohydrate diet, post-weaning period, HOMA-IR, adiponectin.

\section{INTRODUCTION}

Studies have shown that the composition of nutrients consumed by mothers during pregnancy or infants during the first year of life can exert permanent and powerful effects on developing tissues and their function (Langley-Evans 2015).

Correspondence to: Nair Honda Kawashita

E-mail: nairhonda@terra.com.br

ORCid: https://orcid.org/0000-0001-6286-657X
In several occidental societies, during the transition between breastfeeding and weaning, children intake a higher amount of carbohydrate and a lower amount of protein than is recommended for this stage of life (Ramalho et al. 2013).

Aparecida de França et al. (2009), in previous studies in our laboratory, observed that rats maintained on a low-protein, high-carbohydrate (LPHC) diet (6\%-protein, 74\%-carbohydrate) for 
15 days, introduced soon after weaning, ingested a greater amount of food and calories and showed an increase in the energy gain when compared with rats fed on a normal (control) diet (17\%-protein and $63 \%$-carbohydrate). Reduction in the body weight was also observed, although there was an increase in the body lipids in those animals characterizing an adiposity state. Along with these alterations, rats treated with LPHC diet had higher levels of leptin (Aparecida de França et al. 2009), corticosterone and tumor necrosis factor-alpha (TNF $\alpha$ ) in the blood (Santos et al. 2012). Leptin, a hormone primarily synthesized in adipose tissues, normally exhibits a direct relationship with adipose mass, and its action on the hypothalamic neurons inhibits the secretion of orexigenic peptides while increasing secretion of anorexigenic peptides, resulting in reduced food intake (Jequier 2002, Valassi et al. 2008). An increase in serum leptin along with hyperphagia suggests leptin resistance in rats fed an LPHC diet, a condition frequently seen in several types of obesity in humans and rats (Myers et al. 2008, 2010). In turn, high levels of TNF $\alpha$ and corticosterone are associated with insulin resistance due to impairments in the intracellular signaling cascade (Piroli et al. 2007). Although hyperglycemia was not observed in rats fed an LPHC diet, there was a reduction in IRS1 , AKT content and in insulin-stimulated AKT phosphorylation in the retroperitoneal adipose tissue suggesting impaired insulin signaling (Santos et al. 2012). The prevalence of obesity and its association with metabolic syndrome has increased its importance to public health over the last several decades. Metabolic syndrome refers to a group of risk factors associated with overweight and obesity (Grundy 2005, Tkac 2005, Ginsberg and MacCallum 2009, Singh et al. 2010) and is defined as a combination of any three of these disorders: high blood pressure, central adiposity, high serum triglycerides, low serum HDL-cholesterol, and high fasting glycemia (Armitage et al. 2004). Other authors have suggested the inclusion of additional criteria such as oxidative stress, leptin resistance (Arch et al. 1998) and an index of inflammation as TNFa or Interleukin (Reilly and Rader 2003). Based on these references, rats in the growing stage fed with the LPHC diet for 15 days showed several alterations associated with obesity and metabolic syndrome.

Thus, the objective of this investigation was to verify the effects of an LPHC diet introduced soon after weaning, for a longer period (45 days) and rats fed on an LPHC diet for 15 days and then fed a balanced diet for further 30 days, in this case, the objective was to compare the effects of the change for a balanced diet, after a short period on LPHC diet.

\section{MATERIALS AND METHODS}

\section{ANIMALS AND TREATMENT}

Male Wistar rats weighing approximately $100 \mathrm{~g}$ (30 days old) were randomly divided into three groups: 1) a control $\left(\mathrm{C}_{45}\right)$ group, fed a control diet containing $17 \%$-protein and $63 \%$-carbohydrate (AIN-93G; Reeves et al. 1993) for 45 days; 2) a lowprotein, high-carbohydrate $\left(\mathrm{LPHC}_{45}\right)$ group, fed a diet containing 6\%-protein and 74\%-carbohydrate for 45 days; and 3 ) a reverse (R) group, fed an LPHC diet for 15 days followed by a control diet for 30 days. The diets were isocaloric (16.3 $\left.\mathrm{kJ} \cdot \mathrm{g}^{-1}\right)$ in that the calories lost to reduced protein in the LPHC diet were replaced by the calories added by increased carbohydrates (Aparecida de França et al. 2009, Buzelle et al. 2010, Santos et al. 2012, Menezes et al. 2013, Pereira et al. 2017, Silva et al. 2018). Rats were housed individually in metabolic cages in an environmentally-controlled room (light from $6 \mathrm{AM}$ to $6 \mathrm{PM} ; 23 \pm 1{ }^{\circ} \mathrm{C}$ ) and had free access to food and water. Body weight and water and food intake were recorded daily for each rat. Animals were maintained according to the Brazilian College of Animal Experimentation, and 
the study was approved by the Ethics Committee of the Federal University of Mato Grosso (Protocol No. 23108.045355/12-7).

\section{SAMPLE COLLECTION AND BIOCHEMICAL ANALYSES}

All rats were killed by decapitation between 7 AM and $10 \mathrm{AM}$ on $45^{\text {th }}$ day of treatment. Blood samples were collected into anticoagulant-containing tubes to determine, using commercial kits, glucose $\left(\right.$ Labtest $\left.^{\circledR}\right)$, urea $\left(\right.$ Labtest $\left.{ }^{\circledR}\right)$, corticosterone (Cayman Chemical Company, Ann Arbor, MI, USA), glucagon (Wako Chemicals, Inc., Bellwood Road Richmond, VA, USA), leptin (Société de Pharmacologie et d'Immunologie - BIO. Montigny le Bretonneux, France), triiodothyronine (T3), thyroxine (T4) (Interkit, Inc., Vintage Park Drive Foster City, CA, USA), adiponectin (R\&D Systems, Minneapolis, MN, USA) and TNF $\alpha$ (Pierce Biotechnology, Rockford, IL, USA); serum were obtained to determine the concentrations of protein $\left(\right.$ Labtest $\left.^{\circledR}\right)$, triglycerides $\left(\right.$ Labtest $\left.{ }^{\circledR}\right)$, total cholesterol (Labtest $\left.{ }^{\circledR}\right)$, aspartate aminotransferase (AST) $\left(\right.$ Labtest $\left.^{\circledR}\right)$, and alanine aminotransferase (ALT) $\left(\right.$ Labtest $\left.^{\mathbb{B}}\right)$. The liver, extensor digitorum longus (EDL) and soleus muscles, interscapular brown adipose tissue (IBAT), epididymal, retroperitoneal and perirenal white adipose tissues were removed and weighed. Groups of rats were fasted for either $12 \mathrm{~h}$ or $14 \mathrm{~h}$ and sample of blood were collected for determination, using commercial kits, concentration of insulin (Millipore Res., St. Charles, MO, USA), glucose (Labtest $\left.{ }^{\circledR}\right)$, and free fatty acids (FFA) (Wako Chemical ${ }^{\circledR}$, VA, USA).

The homeostasis model assessment of insulin resistance (HOMA-IR) index was calculated for each rat as follows:

HOMA-IR $=$ [fasting insulin $\left(\mu \mathrm{U} \cdot \mathrm{mL}^{-1}\right) \mathrm{x}$ fasting glucose $\left.\left(\mathrm{mmol} \cdot \mathrm{L}^{-1}\right)\right] / 22.5$

This index is a predictor of insulin resistance (Bowe et al. 2014).

\section{BIOMETRIC PARAMETERS}

On day 45, the body mass index (Lee Index) was calculated using the formula (Lee 1928):

$$
\text { Lee Index }=\frac{\sqrt[3]{\text { body weight }(\mathrm{g})}}{\mathrm{ANL}(\mathrm{cm})} \times 1000
$$

where ANL is the anus-nasal length. The Lee Index is used as an index of obesity in rodents (Myers et al. 2010).

\section{CARCASS COMPOSITION AND ENERGY INTAKE}

Carcasses were eviscerated, weighed and stored at $-20^{\circ} \mathrm{C}$. They were used for determination of the body chemical composition and energetic balance.

Carcass composition was determined as described by Aparecida de França et al. (2009). Water content was measured as the difference between wet and dry weights, the latter obtained by ovendrying the carcass to a constant weight. Fat content was calculated by subtracting the fat-free dry mass after extraction with petroleum ether from the dry carcass weight. Ash content was estimated following combustion to a constant weight. Protein content was determined by subtracting the water, fat, and ash contents from the wet carcass weight. To determine the energy gain, an energy baseline was assessed in a group of weaned rats just before introduction to the assigned diet. Energy gain was calculated as the difference between the carcass energy at the end of the experiment and the carcass energy on the first day (baseline), as previously described (Ferreira et al. 2007, Aparecida de França et al. 2009). Carcass energy was calculated as previously described (Aparecida de França et al. 2009).

\section{LIPID AND GLYCOGEN DETERMINATION}

Hepatic lipid content was determined using gravimetric methods after chloroform-methanol (2:1) extraction according to Folch et al. (1957). The method of Carroll et al. (1956) was used to determine hepatic and muscle glycogen content. 


\section{ORAL GLUCOSE TOLERANCE TESTE (OGTT)}

The OGTT was determined as described by Pereira et al. (2014). Rats received, after $15 \mathrm{~h}$ of fasting, a load of $2.5 \mathrm{~g}$ of glucose $\cdot \mathrm{kg}^{-1}$ (orogastric gavage). Plasma glucose was measured in blood withdrawn from the tip of the tail using an Accu-Chek II blood glucose monitor, before load $(t=0)$, and $15,30,60$, 90 , and $120 \mathrm{~min}$ after glucose administration.

\section{STATISTICAL ANALYSIS}

Data were collected, and were subjected to statistical analysis using the Statistics for Windows program (StatSoft, USA) and the GraphPad Prism program. Levene's test for homogeneity of variances was initially used to determine whether the data complied with the assumptions required for parametric analyses of variance. Between-group differences were analyzed using one-way analysis of variance (ANOVA) followed by Tukey's post hoc test. Log transformations were performed to correct heterogeneity in the data of insulin serum in the fed state (Sokal and Rohlf 1995). Food intake data were analyzed by repeated-measures one-way ANOVA. Significance was recognized when $\mathrm{p}<$ 0.05 . The data are presented as mean \pm standard error of the mean.

\section{RESULTS}

FOOD AND PROTEIN INTAKE, BODY WEIGHT GAIN, LEE INDEX

The data on food intake was normalized by body weight and are presented as $\mathrm{g} \cdot 100 \mathrm{~g}^{-1}$ b.w. The $\mathrm{LPHC}_{45}$ rats showed higher food ingestion than the $\mathrm{C}_{45}$ rats, since the first day until one week before the end of the treatment. However, in the last week, the difference started reducing and, on the $45^{\text {th }}$ day of treatment, the food intake of rats of the $\mathrm{LPHC}_{45}$ group was similar to $\mathrm{C}_{45}$ group. In the first 15 days, when they received the LPHC diet, R rats also had higher food intake, but after 5 days on $\mathrm{C}$ diet, they reduced food intake to levels similar to $\mathrm{C}_{45}$ rats (Figure 1). $\mathrm{LPHC}_{45}$ and $\mathrm{R}$ rats ingested about $50 \%$ and $20 \%$ less protein than $\mathrm{C}_{45}$ rats, respectively, although they had ingested more food in the period (27\% and 19\% respectively) when compared with $\mathrm{C}_{45}$ rats (Table I).

The daily body weight gain in $\mathrm{C}_{45}$ rats was $\sim 7 \mathrm{~g} \cdot$ day $^{-1}$ in the first 15 days and $\sim 5 \mathrm{~g} \cdot$ day $^{-1}$ after this period. Rats of $\mathrm{LPHC}_{45}$ group showed a body weight gain of about $4 \mathrm{~g} \cdot \mathrm{day}^{-1}$. The lower daily body weight gain in $\mathrm{LPHC}_{45}$ rats resulted in a lower total body weight than in $\mathrm{C}_{45}$ group at the end of the study. The daily body weight gain in rats of $\mathrm{R}$ group was from $4 \mathrm{~g} \cdot \mathrm{day}^{-1}$ to $6 \mathrm{~g} \cdot \mathrm{day}^{-1}$ when the LPHC diet was changed to $\mathrm{C}$ diet (Supplementary Material - Figure S1). At the end of the study, the $\mathrm{R}$ rats reached the same body weights as $\mathrm{C}_{45}$ rats (Table II). The Lee index was similar among all groups at $45^{\text {th }}$ day (Table II).

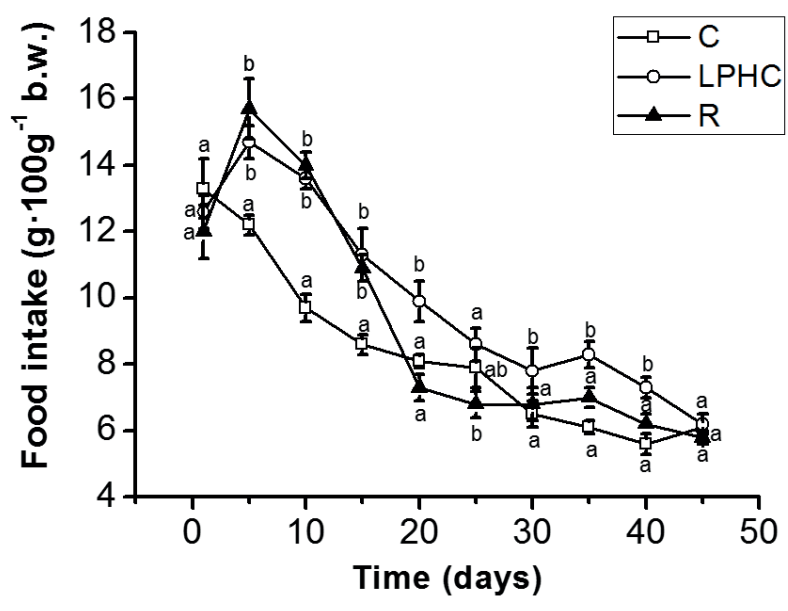

Figure 1 - Relative food intake $\left(\mathrm{g} \cdot 100 \mathrm{~g}^{-1} \cdot\right.$ b.w.) of rats fed with the control diet $\left(\mathrm{C}_{45}=\square\right)$, low-protein, high-carbohydrate diet $\left(\mathrm{LPHC}_{45}=\circ\right)$ for 45 days and rats treated with the LPHC diet for 15 days, followed by the control diet - reverse (R) group $(\mathrm{R}=\mathbf{\Delta})$ until the $45^{\text {th }}$ day. The results are expressed as the means \pm standard error of the mean every five days; $\mathrm{C}_{45}(\mathrm{n}=11), \mathrm{LPHC}_{45}(\mathrm{n}=10)$ and $\mathrm{R}(\mathrm{n}=10)$. Different letters represent significant differences among groups. Repeated measures one-way ANOVA. Treatment (between columns) $\mathrm{F}=$ 23.54; Individual (between rows) $\mathrm{F}=5.94(\mathrm{p}<0.05)$. 
TABLE I

Relative values of daily food intake, total food intake, and total protein intake in $\mathrm{C}_{45}, \mathrm{LPHC}_{45}$, and $\mathrm{R}$ rats.*

\begin{tabular}{|c|c|c|c|c|}
\hline Variable & $\mathrm{C}_{45}$ & $\mathrm{LPHC}_{45}$ & $\mathbf{R}$ & $\mathbf{F}$ \\
\hline \multicolumn{5}{|c|}{ Daily food intake $\left(\mathrm{g} \cdot 100 \mathrm{~g}^{-1}\right.$ b.w.) } \\
\hline (1-15 days) & $11.7 \pm 0.3^{\mathrm{a}}$ & $14.9 \pm 0.5^{\mathrm{b}}$ & $14.9 \pm 0.5^{b}$ & 21.33 \\
\hline (16-45 days) & $6.7 \pm 0.2^{\mathrm{a}}$ & $8.6 \pm 0.2^{\mathrm{b}}$ & $7.4 \pm 0.3^{\mathrm{a}}$ & 21.38 \\
\hline \multicolumn{5}{|c|}{ Total food intake $\left(\mathrm{g} \cdot 100 \mathrm{~g}^{-1}\right.$ b.w.) } \\
\hline (1-45 days) & $376.4 \pm 4.8^{\mathrm{a}}$ & $479.8 \pm 6.9^{\mathrm{b}}$ & $446.7 \pm 7.6^{\mathrm{c}}$ & 72.36 \\
\hline \multicolumn{5}{|c|}{ Total protein intake $\left(\mathrm{g} \cdot 100 \mathrm{~g}^{-1}\right.$ b.w. $)$} \\
\hline (1-45 days) & $64.0 \pm 0.8^{\mathrm{a}}$ & $28.9 \pm 0.4^{\mathrm{b}}$ & $51.3 \pm 1.0^{\mathrm{c}}$ & 525.3 \\
\hline
\end{tabular}

$\mathrm{C}_{45}$, control group; $\mathrm{LPHC}_{45}$, low-protein, high-carbohydrate group; $\mathrm{R}$, reverse group; $\mathrm{F}$ values for ANOVA. *Values are expressed as the means \pm standard error of the mean of 10-11 animals per diet group. Mean values with different lowercase letters are significantly different $\mathrm{p}<0.05$, as determined by one-way ANOVA.

\section{WEIGHT OF THE TISSUES}

The $\mathrm{LPHC}_{45}$ group showed a reduction in the relative weight $\left(\mathrm{g} \cdot 100 \mathrm{~g}^{-1}\right.$ b.w.) of the EDL muscle and an increase in the weight of IBAT when compared with $\mathrm{C}_{45}$ and $\mathrm{R}$ rats. The relative weight of the white adipose tissues (perirenal, epididymal and retroperitoneal) and liver were not different among groups. All the tissues evaluated in $\mathrm{R}$ group showed relative weights similar to $\mathrm{C}_{45}$ rats (Table III).

\section{LIPID AND GLYCOGEN CONTENT}

The lipid content in the liver was similar in $\mathrm{C}_{45}$ and $\mathrm{R}$ rats, but it was higher in $\mathrm{LPHC}_{45}$ rats, when compared with R group. Additionally, the hepatic glycogen content was four-fold higher in $\mathrm{LPHC}_{45}$ rats than in $\mathrm{C}_{45}$ and $\mathrm{R}$ rats. Glycogen contents in the soleus and in the EDL muscles were similar among groups (Table III).

\section{CHEMICAL COMPOSITION AND ENERGETIC BALANCE}

The weight of the carcass was similar among groups (Table IV), but the chemical composition, in percentage, was altered in the $\mathrm{LPHC}_{45}$ group when compared with $\mathrm{C}_{45}$ group. The proteins constituted $21.1 \%$, the fat $14.0 \%$ and ashes $6.2 \%$ in rats treated with $\mathrm{C}$ diet and those percentages were altered in
LHPC $_{45}$ group, respectively: $16.5 \%, 21.7 \%$ and $7.6 \%$. In rats of $\mathrm{R}$ group, the percentages were: $20.0 \%$ protein, $16.9 \%$ fat and $6.3 \%$ ash. R groups showed higher content of protein and lower content of ashes than $\mathrm{LPHC}_{45}$ group. The water content in the carcass was similar among the groups. (Table IV).

The $\mathrm{LPHC}_{45}$ rats ingested higher total energy than $\mathrm{C}_{45}$ rats in the period of 45 days, and showed an increase in the energy expenditure (Table IV). Neither the waste energy nor energy gain were statistically different in $\mathrm{R}$ when compared with $\mathrm{C}_{45}$ rats. They ingested higher total calories than $\mathrm{C}_{45}$ rats but lower than $\mathrm{LPHC}_{45}$ rats.

\section{METABOLITES, HORMONES AND CYTOKINES IN THE BLOOD AND HOMA-IR INDEX}

$\mathrm{LPHC}_{45}$ rats showed lower total protein (22\%), urea (55\%), cHDL (44\%) and FFA (35\%) concentration in the blood when compared with $\mathrm{C}_{45}$ rats. The level of total triglycerides and total cholesterol were not altered by LPHC diet. All these parameters in R rats were similar to $\mathrm{C}_{45}$ rats (Table $\mathrm{V}$ ). However, when the $\mathrm{R}$ group is compared with $\mathrm{LPHC}_{45}$ group, the total cholesterol and cHDL were $27 \%$ and $47 \%$ higher in $\mathrm{R}$ rats (Table V).

The fasting (Figure 2) and fed glycemia (Table V) were alike among the groups and only serum insulin in fed rats of the $\mathrm{R}$ group was higher when 

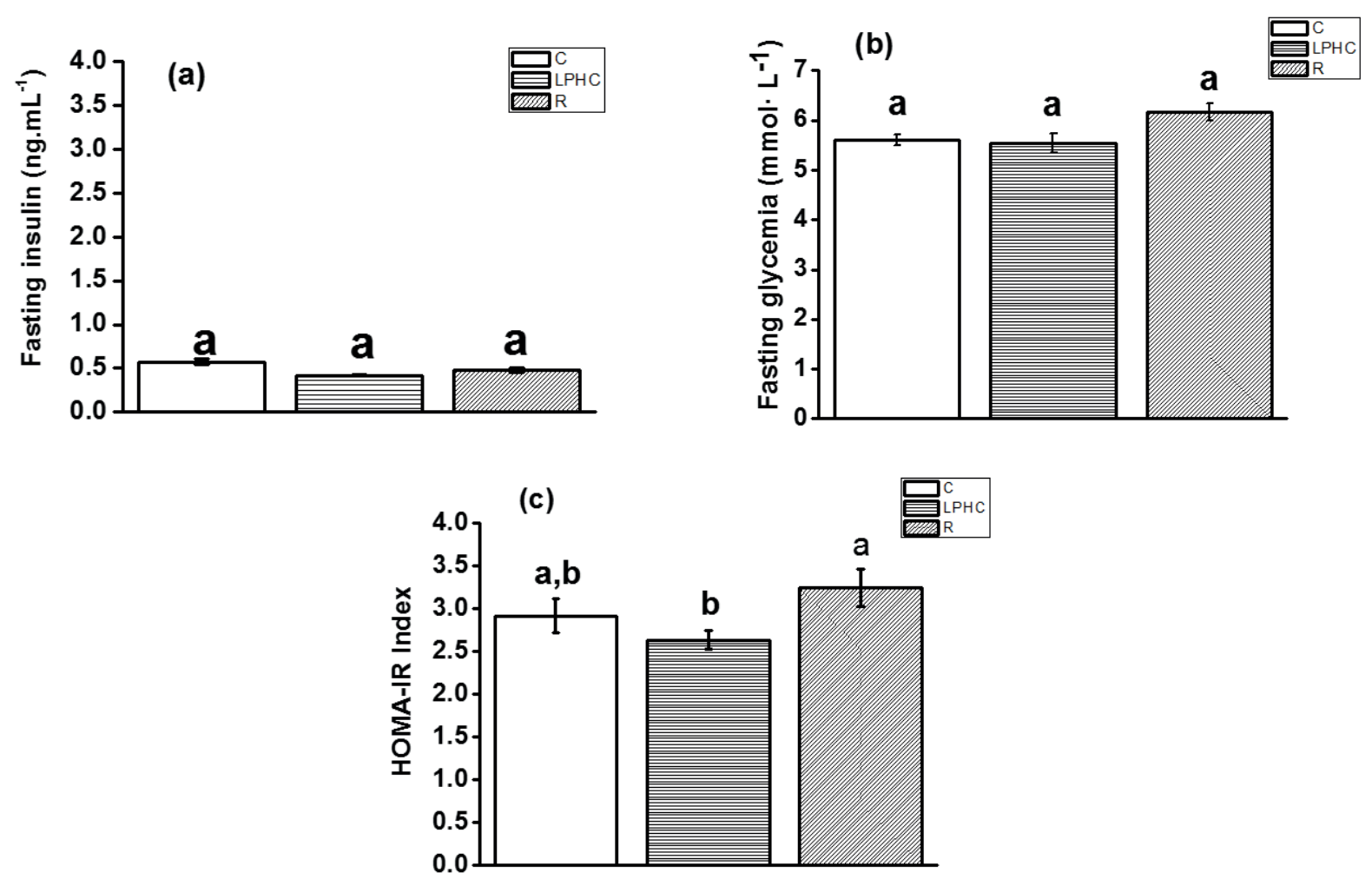

Figure 2 - Serum fasted insulin (a), glycemia (b) and HOMA-IR index (c) of rats fed a control diet or a low-protein, highcarbohydrate ( $\mathrm{LPHC})$ diet for 45 days $\left(\mathrm{C}_{45}\right.$ and $\mathrm{LPHC}_{45}$, respectively) and rats fed an LPHC diet for 15 days followed by the control diet for 30 days $(\mathrm{R})$. Results are expressed as means \pm standard errors of the means across eight animals per group. Letters indicate a significant difference among groups. One-way ANOVA, F = 2.19 for insulin; F = 1.04 for glycemia; F = 4.40 for HOMA-IR Index $(\mathrm{p}<0.05)$.

compared with $\mathrm{C}_{45}$ and $\mathrm{LPHC}_{45}$ group (128\% and $289 \%$, respectively).

HOMA-IR Index in $\mathrm{LPHC}_{45}$ and $\mathrm{R}$ groups was similar to $\mathrm{C}$ group, but $\mathrm{R}$ group showed a higher Index than LPHC $_{45}$ group (Figure 2).

The level of glucagon was similar between $\mathrm{LPHC}_{45}$ and $\mathrm{C}_{45}$ group, but the rats of $\mathrm{R}$ group had lower glucagon level than rats of $\mathrm{C}_{45}$ group. No difference was observed between $\mathrm{LPHC}_{45}$ and $\mathrm{R}$ groups in this parameter. The concentration of adiponectin in the plasma of $\mathrm{LPHC}_{45}$ rats was 2-fold higher when compared with $\mathrm{C}_{45}$ and $\mathrm{R}$ rats; however, it was similar between $\mathrm{C}_{45}$ and $\mathrm{R}$ groups themselves (Figure 3). The level of T3 was increased in $\mathrm{LPHC}_{45}$ group and $\mathrm{T} 4$ in $\mathrm{R}$ group when compared with $\mathrm{C}_{45}$ group, however, there was no difference between $\mathrm{LPHC}_{45}$ and $\mathrm{R}$ neither in $\mathrm{T} 3$ nor in T4 (Table V).

The level of leptin, TNF $\alpha$ and corticosterone were similar among all the groups, as well as the AST and ALT transaminase measured in the blood (Table V).

\section{ORAL GLUCOSE TOLERANCE TEST (OGTT)}

Glucose tolerance in animals was evaluated by Area Under the Curve (AUC) distribution, determined by glucose concentration in the blood at different times, after overload of glucose. Rats of $\mathrm{LPHC}_{45}$ group showed lower AUC than C. The AUC of R and $\mathrm{C}_{45}$ rats was similar. Therefore, comparing the three groups, only the treatment with LPHC diet for 45 days increased glucose tolerance (Figure 4). 
TABLE II

The initial and final body weights and Lee indices for $\mathrm{C}_{45}, \mathrm{LPHC}_{45}$, and $\mathrm{R}$ rats.*

\begin{tabular}{lcccc}
\hline \multicolumn{1}{c}{ Variable } & $\mathbf{C}_{45}$ & LPHC $_{45}$ & $\mathbf{R}$ & $\mathbf{F}$ \\
\hline Initial body weight $(\mathrm{g})$ & $98.5 \pm 3.2^{\mathrm{a}}$ & $96.8 \pm 2.2^{\mathrm{a}}$ & $95.9 \pm 1.6^{\mathrm{a}}$ & 0.78 \\
Final body weight $(\mathrm{g})$ & $368.5 \pm 3.1^{\mathrm{a}}$ & $303.2 \pm 6.5^{\mathrm{b}}$ & $350.0 \pm 8.9^{\mathrm{a}}$ & 27.24 \\
Lee index & $299.7 \pm 3.2^{\mathrm{a}}$ & $297.5 \pm 2.6^{\mathrm{a}}$ & $294.6 \pm 2.5^{\mathrm{a}}$ & 0.80 \\
\hline
\end{tabular}

$\mathrm{C}_{45}$, control group; $\mathrm{LPHC}_{45}$, low-protein, high-carbohydrate group; $\mathrm{R}$, reverse group; $\mathrm{F}$ values for ANOVA. *Values are expressed as the means \pm standard error of 10-11 animals per diet group. Mean values with different lowercase letters are significantly different $(\mathrm{p}<0.05)$, as determined by one-way ANOVA.

TABLE III

Tissue weights, liver lipid and glycogen contents, retroperitoneal, epididymal, perirenal, and interscapular brown adipose tissue (IBAT) weights, and soleus and extensor digitorum longus (EDL) muscle weights in $\mathrm{C}_{45}, \mathrm{LPHC}_{45}$, and $\mathrm{R}$ rats.*

\begin{tabular}{|c|c|c|c|c|c|c|c|c|}
\hline \multirow[b]{2}{*}{ Variable } & \multicolumn{4}{|c|}{ Tissue weights $\left(\mathrm{g} \cdot 100 \mathrm{~g}^{-1}\right.$ b.w. $)$} & \multicolumn{4}{|c|}{ Lipids ( $\mathrm{mg} \cdot \mathrm{g}^{-1}$ of tissue) } \\
\hline & $\mathrm{C}_{45}$ & $\mathrm{LPHC}_{45}$ & $\mathbf{R}$ & $\mathbf{F}$ & $\mathrm{C}_{45}$ & $\mathrm{LPHC}_{45}$ & $\mathbf{R}$ & $\mathbf{F}$ \\
\hline Liver & $3.61 \pm 0.09^{\mathrm{a}}$ & $3.88 \pm 0.15^{\mathrm{a}}$ & $3.77 \pm 0.14^{\mathrm{a}}$ & 1.10 & $19.1 \pm 2.1^{\mathrm{ab}}$ & $29.5 \pm 5.7^{\mathrm{a}}$ & $15.5 \pm 2.3^{\mathrm{b}}$ & 3.57 \\
\hline Retroperitoneal & $1.97 \pm 0.12^{\mathrm{a}}$ & $2.09 \pm 0.11^{\mathrm{a}}$ & $1.86 \pm 0.14^{\mathrm{a}}$ & 0.86 & - & - & - & - \\
\hline Epididymal & $2.11 \pm 0.13^{\mathrm{a}}$ & $2.26 \pm 0.09^{\mathrm{a}}$ & $2.07 \pm 0.19^{\mathrm{a}}$ & 0.61 & - & - & - & - \\
\hline Perirenal & $0.35 \pm 0.04^{\mathrm{a}}$ & $0.35 \pm 0.02^{\mathrm{a}}$ & $0.35 \pm 0.02^{\mathrm{a}}$ & 1.00 & - & - & - & - \\
\hline \multirow[t]{2}{*}{ IBAT } & $0.16 \pm 0.01^{\mathrm{a}}$ & $0.25 \pm 0.01^{\mathrm{b}}$ & $0.18 \pm 0.01^{\mathrm{a}}$ & 22.33 & - & - & - & - \\
\hline & & & & & \multicolumn{4}{|c|}{ Glycogen ( $\mathrm{mg} \cdot \mathrm{g}^{-1}$ of tissue) } \\
\hline Liver & $3.61 \pm 0.09^{\mathrm{a}}$ & $3.88 \pm 0.15^{\mathrm{a}}$ & $3.77 \pm 0.14^{\mathrm{a}}$ & 1.10 & $21.5 \pm 5.9^{\mathrm{a}}$ & $90.3 \pm 16.1^{\mathrm{b}}$ & $29.7 \pm 7.2^{\mathrm{a}}$ & 13.81 \\
\hline Soleus & $0.083 \pm 0.003^{\mathrm{a}}$ & $0.077 \pm 0.004^{\mathrm{a}}$ & $0.081 \pm 0.002^{\mathrm{a}}$ & 0.96 & $1.07 \pm 0.42^{\mathrm{a}}$ & $0.82 \pm 0.30^{\mathrm{a}}$ & $1.62 \pm 0.48^{\mathrm{a}}$ & 0.49 \\
\hline EDL & $0.080 \pm 0.002^{\mathrm{a}}$ & $0.070 \pm 0.001^{\mathrm{b}}$ & $0.077 \pm 0.002^{\mathrm{a}}$ & 8.77 & $0.70 \pm 0.42^{\mathrm{a}}$ & $0.44 \pm 0.12^{\mathrm{a}}$ & $0.23 \pm 0.13^{\mathrm{a}}$ & 0.97 \\
\hline
\end{tabular}

$\mathrm{C}_{45}$, control group; $\mathrm{LPHC}_{45}$, low-protein, high-carbohydrate group; $\mathrm{R}$, reverse group; EDL, extensor digitorum longus muscle; $\mathrm{F}$ values for ANOVA.* Values are expressed as the means \pm standard error of 5-7 animals per diet group. Mean values with different lowercase letters are significantly different $(\mathrm{p}<0.05)$, as determined by one-way ANOVA.

\section{DISCUSSION}

Our objective in this work was to verify the effects of the LPHC diet when administered to growing rats for 45 days and the effects of the exchange by $\mathrm{C}$ (balance) diet after a short period on LPHC diet.

Rats treated with an LPHC diet for 45 days consumed $22 \%$ more calories than the rats of the $\mathrm{C}_{45}$ group. However, they showed similar energy gain during this period due to the increase in energy expenditure. Thermogenesis in BAT is an important component of the energetic balance in rodents. Thermogenesis induced by a low-protein diet has previously been described and involves an increase in BAT mass, a rise in the sympathetic flux, and higher energy dissipated as heat (Stirling and Stock 1968, Rothwell et al. 1983). Consistent with that hypothesis, $\mathrm{LPHC}_{45}$ rats showed, in addition to increased $\mathrm{T}_{3}$ levels, higher relative food intake, higher energy expenditure, and increased IBAT weights than $\mathrm{C}_{45}$ rats A previous study conducted at our laboratory (Aparecida de França et al. 2009) showed that rats fed on an LPHC diet for 15 days had a higher sympathetic flux to IBAT, activating thermogenesis and increasing UCP1 expression in the tissue via p38 MAPK and ATF2. Thus, we concluded that the adaptation to the LPHC diet reduced food efficiency in the rats and contributed 
TABLE IV

Carcass composition and energetic balance in $\mathrm{C}_{45}$, $\mathrm{LPHC}_{45}$, and $\mathrm{R}$ rats.*

\begin{tabular}{|c|c|c|c|c|}
\hline \multicolumn{5}{|c|}{ Carcass composition } \\
\hline Variable & $\mathrm{C}_{45}$ & LPHC $_{45}$ & $\mathbf{R}$ & $\mathbf{F}$ \\
\hline Carcass weight (g) & $271.5 \pm 9.2^{\mathrm{a}}$ & $247.7 \pm 12.3^{\mathrm{a}}$ & $281.5 \pm 8.9^{\mathrm{a}}$ & 2.85 \\
\hline Water $(\%)$ & $58.7 \pm 1.0^{\mathrm{a}}$ & $54.2 \pm 1.2^{\mathrm{a}}$ & $56.8 \pm 1.7^{\mathrm{a}}$ & 2.74 \\
\hline Fat $(\%)$ & $14.0 \pm 1.4^{\mathrm{a}}$ & $21.7 \pm 1.9^{b}$ & $16.9 \pm 2.2^{\mathrm{a}, \mathrm{b}}$ & 4.36 \\
\hline Protein $(\%)$ & $21.1 \pm 0.7^{\mathrm{a}}$ & $16.5 \pm 0.7^{\mathrm{b}}$ & $20.0 \pm 0.7^{\mathrm{a}}$ & 11.78 \\
\hline Ash $(\%)$ & $6.2 \pm 0.3^{\mathrm{a}}$ & $7.6 \pm 0.1^{\mathrm{b}}$ & $6.3 \pm 0.3^{\mathrm{a}}$ & 9.63 \\
\hline \multicolumn{5}{|c|}{ Energetic balance } \\
\hline Variable & $\mathrm{C}_{45}$ & $\mathrm{LPHC}_{45}$ & $\mathbf{R}$ & $\mathbf{F}$ \\
\hline Daily energy intake (kJ·100g ${ }^{-1}$ b.w.) & $83.7 \pm 1.1^{\mathrm{a}}$ & $102.9 \pm 1.3^{\mathrm{b}}$ & $88.1 \pm 0.4^{\mathrm{c}}$ & 106.32 \\
\hline Total energy intake $\left(\mathrm{kJ} \cdot 100 \mathrm{~g}^{-1} \mathrm{~b} . \mathrm{w}.\right)$ & $3766.8 \pm 46.9^{\mathrm{a}}$ & $4617.1 \pm 53.6^{\mathrm{b}}$ & $3962.5 \pm 17.4^{\mathrm{c}}$ & 110.49 \\
\hline $\begin{array}{l}\text { Energy gain } \\
\left(\mathrm{kJ} \cdot 100 \mathrm{~g}^{-1} \text { b.w.) }\right.\end{array}$ & $827.0 \pm 47.7^{\mathrm{a}}$ & $1000.0 \pm 67.2^{\mathrm{a}}$ & $907.5 \pm 86.2^{\mathrm{a}}$ & 1.58 \\
\hline Energy expenditure $\left(\mathrm{kJ} \cdot 100 \mathrm{~g}^{-1}\right.$ b.w.) & $4188.8 \pm 80.5^{\mathrm{a}}$ & $5185.0 \pm 129.3^{\mathrm{b}}$ & $4394.0 \pm 77.7^{\mathrm{a}}$ & 28.40 \\
\hline $\begin{array}{l}\text { Carcass energy } \\
\left(\mathrm{kJ} \cdot 100 \mathrm{~g}^{-1} \text { b.w.) }\right.\end{array}$ & $1055.9 \pm 41.7^{\mathrm{a}}$ & $1252.0 \pm 59.3^{\mathrm{a}}$ & $1128.1 \pm 81.9^{\mathrm{a}}$ & 2.47 \\
\hline Baseline carcass $(\mathrm{kJ})$ & $618.4 \pm 29.1^{\mathrm{a}}$ & $618.4 \pm 29.1^{\mathrm{a}}$ & $618.4 \pm 29.1^{\mathrm{a}}$ & 2.86 \\
\hline
\end{tabular}

$\mathrm{C}_{45}$, control group; $\mathrm{LPHC}_{45}$, low-protein, high-carbohydrate group; $\mathrm{R}$, reverse group; F values for ANOVA. *Values are expressed as the means \pm standard error of the mean of 5 animals per diet group. Mean values with different lowercase letters are significantly different $(p<0.05)$, as determined by one-way ANOVA.

to the maintenance of the adipose tissue depots and Lee index similar to $\mathrm{C}_{45}$ rats.

The increase in food intake is an adaptation of the organism to reach its protein requirement when species are fed with a diet with low protein content (Whitaker et al. 2011). However, the lower content of total protein and urea in the blood, of protein content in the carcass and the impaired development of the muscles in rats of the $\mathrm{LPHC}_{45}$ group show that the higher food intake was not enough to supply the animals with the requirement of proteins necessary in this phase of life. The protein intake in $\mathrm{LPHC}_{45}$ group was 55\% lower than in $\mathrm{C}_{45}$ rats. Miñana-Solis and Escobar (2008) found similar results with post-weaned rats (25 days old) receiving a low-protein (6\%) diet for 30 days. They had lower body mass gains, resulting in lower final body weights, compared with controls. Aparecida de França et al. (2009) also observed a lower intake of protein in animals submitted to an

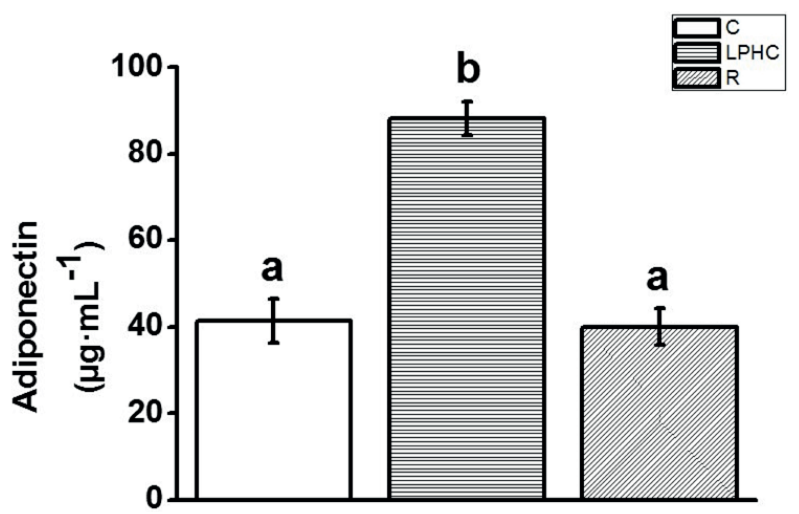

Figure 3 - Serum adiponectin levels in rats fed a control diet for 45 days $\left(\mathrm{C}_{45}\right)$, a low-protein, high-carbohydrate (LPHC) diet for 45 days or an LPHC diet for 15 days followed by a control diet for 30 days (R). Results are expressed as means \pm standard errors of the means across eight animals per group. Statistical analysis was performed using ANOVA (one-way ANOVA, $F=8.65)$. Letters indicate significant differences among groups $(\mathrm{p}<0.05)$.

LPHC diet for 15 days (about $60 \%$ ), despite the $14 \%$ increase in food intake.

Besides higher food intake by rats of the $\mathrm{LPHC}_{45}$ group, the LPHC diet is a hyperglycemic 

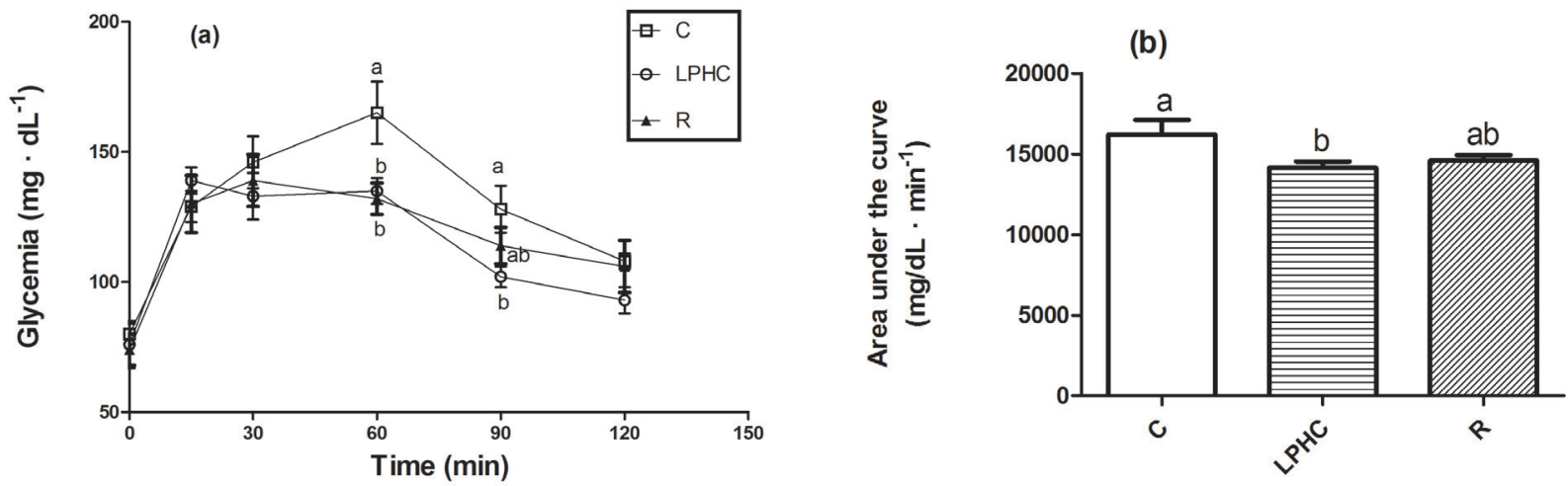

Figure 4 - Serum glucose $(\mathrm{mg} / \mathrm{dL})$ (a) and area under the curve (b) of the oral glucose-tolerance test (OGTT) of rats treated with the control diet (C group) or low-protein, high-carbohydrate diet (LPHC group) for 45 days and rats treated with the LPHC diet for 15 days followed by the control diet until the 45th day ( $\mathrm{R}$ group). The results are expressed as the means \pm standard error of the mean of seven animals per group. Different letters represent significant differences among groups. One-way ANOVA ( $<<0.05$ ).

TABLE V

Blood biochemical, hormone, and cytokine analyses in $\mathrm{C}_{45}, \mathrm{LPHC}_{45}$, and $\mathrm{R}$ rats.*

\begin{tabular}{|c|c|c|c|c|}
\hline \multicolumn{5}{|c|}{ Biochemical analyses } \\
\hline Variable & $\mathrm{C}_{45}$ & $\mathrm{LPHC}_{45}$ & $\mathbf{R}$ & $\mathbf{F}$ \\
\hline Fed glycemia $\left(\mathrm{mg} \cdot \mathrm{dL}^{-1}\right)$ & $129 \pm 7^{\mathrm{a}}$ & $120 \pm 4^{\mathrm{a}}$ & $130 \pm 8^{\mathrm{a}}$ & 0.64 \\
\hline Total protein $\left(\mathrm{g} \cdot \mathrm{dL}^{-1}\right)$ & $6.4 \pm 0.2^{\mathrm{a}}$ & $5.0 \pm 0.2^{\mathrm{b}}$ & $7.0 \pm 0.2^{\mathrm{a}}$ & 22.82 \\
\hline Urea $\left(\mathrm{mg} \cdot \mathrm{dL}^{-1}\right)$ & $38 \pm 2^{\mathrm{a}}$ & $17 \pm 1^{\mathrm{b}}$ & $38 \pm 1^{\mathrm{a}}$ & 96.74 \\
\hline $\operatorname{ALT}\left(\mathrm{U} \cdot \mathrm{dL}^{-1}\right)$ & $30 \pm 3^{\mathrm{a}}$ & $34 \pm 3^{\mathrm{a}}$ & $33 \pm 23^{\mathrm{a}}$ & 0.48 \\
\hline $\operatorname{AST}\left(\mathrm{U} \cdot \mathrm{dL}^{-1}\right)$ & $113 \pm 11^{\mathrm{a}}$ & $91 \pm 7^{\mathrm{a}}$ & $86 \pm 3^{\mathrm{a}}$ & 3.38 \\
\hline Triglycerides $\left(\mathrm{mg} \cdot \mathrm{dL}^{-1}\right)$ & $139 \pm 9^{\mathrm{a}}$ & $123 \pm 6^{\mathrm{a}}$ & $150 \pm 13^{\mathrm{a}}$ & 1.92 \\
\hline Total cholesterol $\left(\mathrm{mg} \cdot \mathrm{dL}^{-1}\right)$ & $143 \pm 7^{\mathrm{ab}}$ & $127 \pm 8^{\mathrm{a}}$ & $162 \pm 10^{\mathrm{b}}$ & 4.51 \\
\hline HDL-cholesterol $\left(\mathrm{mg} \cdot \mathrm{dL}^{-1}\right)$ & $105 \pm 8^{\mathrm{a}}$ & $59 \pm 7^{\mathrm{b}}$ & $87 \pm 8^{\mathrm{a}}$ & 23.56 \\
\hline Free fatty acid $\left(\mathrm{Eq} \cdot \mathrm{mL}^{-1}\right)$ & $222 \pm 22^{\mathrm{a}}$ & $144 \pm 9^{\mathrm{b}}$ & $189 \pm 11^{\mathrm{ab}}$ & 6.33 \\
\hline
\end{tabular}

\begin{tabular}{lcccc}
\hline & Hormones and cytokines analyses & & \\
\hline Variable & \multicolumn{1}{c}{$\mathbf{C}_{45}$} & LPHC $_{45}$ & $\mathbf{R}$ & F \\
\hline Fed insulin $\left(\mathrm{ng} \cdot \mathrm{mL}^{-1}\right)$ & $1.260 \pm 0.235^{\mathrm{a}}$ & $0.738 \pm 0.049^{\mathrm{a}}$ & $2.874 \pm 0.745^{\mathrm{b}}$ & 9.92 \\
Glucagon $\left(\mathrm{ng} \cdot \mathrm{mL}^{-1}\right)$ & $0.321 \pm 0.016^{\mathrm{a}}$ & $0.257 \pm 0.027^{\mathrm{ab}}$ & $0.245 \pm 0.014^{\mathrm{b}}$ & 4.69 \\
Leptin $\left(\mathrm{ng} \cdot \mathrm{mL}^{-1}\right)$ & $5.51 \pm 1.87^{\mathrm{a}}$ & $5.68 \pm 1.38^{\mathrm{a}}$ & $6.33 \pm 0.95^{\mathrm{a}}$ & 0.09 \\
$\mathrm{~T} 3\left(\mathrm{ng} \cdot \mathrm{mL}^{-1}\right)$ & $2.48 \pm 0.02^{\mathrm{a}}$ & $2.65 \pm 0.06^{\mathrm{b}}$ & $2.62 \pm 0.03^{\mathrm{ab}}$ & 4.19 \\
$\mathrm{~T} 4\left(\mathrm{ng} \cdot \mathrm{mL}^{-1}\right)$ & $3.08 \pm 0.01^{\mathrm{a}}$ & $3.10 \pm 0.01^{\mathrm{ab}}$ & $3.12 \pm 0.01^{\mathrm{b}}$ & 6.23 \\
$\mathrm{TNF} \alpha\left(\mathrm{pg} \cdot \mathrm{mL}^{-1}\right)$ & $248.51 \pm 32.93^{\mathrm{a}}$ & $257.37 \pm 16.52^{\mathrm{a}}$ & $276.17 \pm 38.00^{\mathrm{a}}$ & 0.21 \\
Corticosterone $\left(\mathrm{ng} \cdot \mathrm{mL}^{-1}\right)$ & $20.27 \pm 3.05^{\mathrm{a}}$ & $24.56 \pm 5.50^{\mathrm{a}}$ & $12.85 \pm 3.50^{\mathrm{a}}$ & 2.03 \\
\hline
\end{tabular}

$\mathrm{C}_{45}$, control group; $\mathrm{LPHC}_{45}$, low-protein, high-carbohydrate group; R, reverse group; ALT, alanine aminotransferase; AST, aspartate aminotransferase; $F$ values for ANOVA. *Values are expressed as the means \pm standard error of the mean of 8 animals per diet group. Mean values with different lowercase letters are significantly different $(p<0.05)$, as determined by one-way ANOVA.

diet (LPHC - 74\%-carbohydrate and C diet$63 \%$-carbohydrate). Therefore, the animals of $\mathrm{LPHC}_{45}$ group intake $47 \%$ more carbohydrate than $\mathrm{C}_{45}$ group. The storage of glycogen per gram of tissue, was maintained in the muscles of the $\mathrm{LPHC}_{45}$ group; but the glycogen content in the liver was about 4-fold higher, when compared with $\mathrm{C}_{45}$ group. The different effects obtained on glycogen depot 
in the liver (increased) and in the muscle (similar among groups) can be explained by presence of different enzymatic isoforms. Glycogen synthase (GS) catalyses the incorporation of glucose to a growing glycogen molecule via $\alpha$-1,4-glycosidic bonds. Mammals have two main GS isoforms designated as muscle GS (MGS) and liver GS (LGS). The two isoforms have different intracellular distribution and molecular mechanisms involved in their controls. Both Hexokinase I and MGS are sensitive to the low concentrations of glucose. In the liver, only when blood glucose concentration increases above a threshold level the Glucokinase (hexoquinase isoform in the liver) increases the glucose phosphorylation to glucose-6-phosphate, thus giving the signal that triggers the synthesis of hepatic glycogen. It seems that LGS is one way for the hepatocyte to ensure hepatic glycogen synthesis when blood glucose levels are high (Gomis et al. 2002).

It is also presumable that the $\mathrm{LPHC}_{45}$ rats use part of the glucose excess from the diet for the synthesis of non-essential amino acids and lipids. We observed a $270 \%$ increase in the rate of fatty acid synthesis from glucose in rats which received the LPHC diet for 15 days (Menezes et al. 2013). Levels of non-essential amino acids were preserved or even increased in the plasma of those rats probably due the Carbons from glycolysis and Krebs Cycle intermediates (Batistela et al. 2014). The increase in glucose tolerance and similar HOMA-IR index in $\mathrm{LPHC}_{45}$ rats suggest that the increase occurred without altering in insulin resistance. The higher tolerance to glucose overload was also observed in animals fed an LPHC diet for 15 days (Pereira et al. 2014). The increase in the adiponectin level may have contributed for a better response of $\mathrm{LPHC}_{45}$ rats to glucose overload. Yamauchi et al. (2001) observed that adiponectin replacement in adiponectin deficiency mouse model increased PPAR-alpha expression, fatty acid oxidation, and energy consumption, causing a reduction of triglyceride content in muscle and liver. In the skeletal muscle, the decrease in triglyceride content was associated with increased GLUT-4 translocation, which led to improved insulin sensitivity. The adiponectin gene expression in adipose tissue significantly correlates with plasma levels and higher sensitivity to insulin action, higher glucose uptake and higher fatty acid oxidation (Bollen et al. 1998, Yamauchi et al. 2001, 2002).

The rats of the R group showed a slight increase in total food and calories intake in the experimental period in consequence of the higher intake of the diet when the group was submitted to 15 days on LPHC diet. The body weight, body chemistry composition and the other energetic parameters were similar to rats of the $\mathrm{C}_{45}$ group. At the end of the 45 days, we observed that the change for $\mathrm{C}$ diet in $\mathrm{R}$ rats was efficient in compensating the consequences of the lower content of protein in the LPHC diet administered for 15 days. Only T4 and fed insulin were increased in the blood of $\mathrm{R}$ rats as compared with $\mathrm{C}_{45}$ rats. The low protein content in the diet has already been associated with low serum thyroid hormones in other several studies (Gão et al. 2013, Palkowaska-Gozdzik et al. 2017).

The hyperinsulinaemia observed in $\mathrm{R}$ rats is supported by other investigations in animals submitted to a diet poor in protein. Studies using 30-d-old C57BL/6 mice exposed to a proteinrestricted diet for 14 weeks showed that they produce and secrete less insulin, but they also remove and degrade less insulin, due to the lower expression of the insulin-degrading enzyme in the liver, possibly with long-term consequences. Thus, the reduced insulin clearance to control hypoinsulinaemia in malnourished mice might lead to hyperinsulinaemia, when they are exposed to a normal and/or a high-nutrient diet (Rezende et al. 2014). The higher HOMA-IR index in $\mathrm{R}$ rats compared with $\mathrm{LPHC}_{45}$ rats (but not with $\mathrm{C}_{45}$ rats), did not seem to have significance in vivo, since 
it was not accompanied by alterations in the area under curve in the OGTT used to evaluate glucose tolerance.

Thus, the data suggest that the different response in $\mathrm{LPHC}_{45}$ as compared with $\mathrm{C}_{45}$ rats (increased glucose tolerance, hepatic glycogen and lower fatty acid) and in R group as compared with $\mathrm{LPHC}_{45}$ (increased total cholesterol, insulin resistance and fed insulin), can be related to different levels of adiponectin among groups.

\section{AUTHOR CONTRIBUTIONS}

Researchers P.C. and S.A.F. carried out biochemical analyzed and carcass composition. M.F. and M.P.S. carried out hormonal analyses. M.P.P. and T.S.Q. carried out lipid and glycogen determinations and F.H.S.S. carried out oral glucose tolerance test. Researchers P.C.L., C.M.B.A. and A.M.B. read the manuscript and contributed to the discussion. N.H.K. designed the experiment, helped analyze the data, wrote the manuscript, and supervised the project. All authors read and approved the final manuscript.

\section{REFERENCES}

APARECIDA DE FRANCA S, DOS SANTOS MP, GAROFALO MA, NAVEGANTES LC, KETTELHUT IC, LOPES CF AND KAWASHITA NH. 2009. Low protein diet changes the energetic balance and sympathetic activity in brown adipose tissue of growing rats. Nutrition 25: 1186-1192.

ARCH JR, STOCK MJ AND TRAYHURN P. 1998. Leptin resistance in obese humans: does it exist and what does it mean? Int J Obes Relat Metab Disord 22: 1159-1163.

ARMITAGE JA, KHAN IY, TAYLOR PD, NATHANIELSZ PW AND POSTON L. 2004. Developmental programming of the metabolic syndrome by maternal nutritional imbalance: how strong is the evidence from experimental models in mammals? J Physiol 561: 355-377.

BATISTELA E ET AL. 2014. Decreased rate of protein synthesis, caspase-3 activity, and ubiquitin-proteasome proteolysis in soleus muscles from growing rats fed a lowprotein, high-carbohydrate diet. Can J Physiol Pharmacol 92(6): 445-454.
BOLLEN M, KEPPENS S AND STALMAN W. 1998. Specific features of glycogen metabolism in the liver. Biochem $\mathrm{J}$ 336(1): 19-31.

BOWE JE, FRANKLIN ZJ, HAUGE-EVANS AC, KING AJ, PERSAUD SJ AND JONES PM. 2014. Metabolic phenotyping guidelines: Assessing glucose homeostasis in rodent models. J Endocrinol 222: 13-25.

BUZELLE SL, SANTOS MP, BAVIERA AM, LOPES CF, GARÓFALO MA, NAVEGANTES LC, KETTELHUT IC, CHAVES VE AND KAWASHITA NH. 2010. A lowprotein, high-carbohydrate diet increases the adipose lipid content without increasing the glycerol-3-phosphate or fatty acid content in growing rats. Can J Physiol Pharmacol 88(12): 1157-1165.

CARROLL NV, LONGLAY RW AND ROE JH. 1956. The determination of glycogen in liver and muscle by use of anthrone reagents. J Biol Chem 220: 583-593.

FERREIRA CL, MACEDO GM, LATORRACA MQ, ARANTES VC, VELOSO RV, CARNEIRO EM, BOSCHERO AC, NASCIMENTO CM AND GAÍVA MH. 2007. Serum leptin and insulin levels in lactating protein-restricted rats: implications for energy balance. $\mathrm{Br}$ J Nutr 97: 27-34.

FOLCH J, LEES M AND SLOANE STANLEY GH. 1957. A simple method for the isolation and purification of total lipides from animal tissues. J Biol Chem 226: 497-509.

GAO J, LIN X, LIU X, YANG Q, ZHANG Z, JIANG Q AND BIAN J. 2013. Effect of combined excess iodine and lowprotein diet on thyroid hormones and ultrastructure in wistar rats. Biol Trace Elem Res 155(3): 416-422.

GINSBERG HN AND MACCALLUM PR. 2009. The obesity, metabolic syndrome, and type 2 diabetes mellitus pandemic: Part I. Increased cardiovascular disease risk and the importance of atherogenic dyslipidemia in persons with the metabolic syndrome and type 2 diabetes mellitus. J Cardiometab Syndr 4: 113-119.

GOMIS RR, CID E, GARCÍA-ROCHA M, FERRER JC AND GUINOVART JJ. 2002. Liver glycogen synthese but not the muscle isoform differentiates between glucose 6-phosphate produced by glucokinase or hexokinase. Biol Chen 277(26): 23246-23252.

GRUNDY SM. 2005. A constellation of complications: the metabolic syndrome. Clin Cornerstone 7: 36-45.

JEQUIER E. 2002. Leptin signaling, adiposity, and energy balance. Ann N Y Acad Sci 967: 379-388.

LANGLEY-EVANS SC. 2015. Nutrition in early life and the programming of adult disease: a review. J Hum Nutr Diet 28(Suppl 1): 1-14.

LEE MO. 1928. Determination of the surface area of the white rat with its application to the expression of metabolic results. Am J Physiol 89: 24-33.

MENEZES AL ET AL. 2013. A Low-protein, highcarbohydrate diet increases de novo fatty acid synthesis 
from glycerol and glycerokinase content in the liver of growing rats. Nutr Res 33(6): 494-502.

MIÑANA-SOLIS MDEL C AND ESCOBAR C. 2008. Postweaning protein malnutrition in the rat produces short and long term metabolic impairment, in contrast to earlier and later periods. Int J Biol Sci 4: 422-432.

MYERS MG, COWLEY MA AND MUNZBERG H. 2008. Mechanisms of leptin action and leptin resistance. Annu Rev Physiol 70: 537-556.

MYERS MG JR, LEIBEL RL, SEELEY RJ AND SCHWARTZ MW. 2010. Obesity and leptin resistance: distinguishing cause from effect. Trends Endocrinol Metab 21: 643-651.

PALKOWASKA-GOZDZIK E, LACHOWICZ K AND ROSOLOWSKA-HUSZCZ D. 2017. Effects of dietary protein on thyroid axis activity. Nutrients 10(1): 1-15.

PEREIRA MP ET AL. 2014. High glucose uptake in growing rats adapted to a low-protein, high-carbohydrate diet determines low fasting glycemia even with high hepatic gluconeogenesis. Can J Physiol Pharmacol 92(6): 460466.

PEREIRA MP, FERREIRA LAA, DA SILVA FHS, CHRISTOFFOLETE MA, METSIOS GS, CHAVES VE, DE FRANÇA SA, DAMAZO AS, FLOURIS AD AND KAWASHITANH. 2017. A low-protein, high-carbohydrate diet increases browning in perirenal adipose tissue but not in inguinal adipose tissue. Nutrition 42: 37-45.

PIROLI GG, GRILLO CA, REZNIKOV LR, ADAMS S, MCEWEN BS, CHARRON MJ AND REAGAN LP. 2007. Corticosterone impairs insulin-stimulated translocation of GLUT4 in the rat hippocampus. Neuroendocrinology 85: 71-80.

RAMALHO AA ET AL. 2013. Nutritional status of children under 5 years of age in the Brazilian Western Amazon before and after the interoceanic highway paving: a population base study. BMC Public Health 13: 1098.

REEVES PG, NIELSEN FH AND FAHEY GC JR. 1993. AIN93 purified diets for laboratory rodents: final report of the American Institute of Nutrition ad hoc writing committee on the reformulation of the AIN-76A rodent diet. J Nutr 123: 1939-1951.

REILLY MP AND RADER DJ. 2003. The metabolic syndrome: more than the sum of its parts? Circulation 108: 1546-1551.

REZENDE LF, CAMARGO RL, BRANCO RC, CAPPELLI AP, BOSCHERO AC AND CARNEIRO EM. 2014. Reduced insulin clearance and lower insulin-degrading enzyme expression in the liver might contribute to the thrifty phenotype of protein-restricted mice. Br J Nutr 112(6): 900-907.

ROTHWELL NJ, STOCK MJ AND TYZBIR RS. 1983. Mechanisms of thermogenesis induced by low protein diets. Metabolism 32: 257-261.

SANTOS MP, FRANCA SA, SANTOS JT, BUZELLE SL, BERTOLINI GL, GARÓFALO MA, KETTELHUT IC, FRASSON D, CHAVES VE AND KAWASHITA NH. 2012. A low-protein, high-carbohydrate diet increases fatty acid uptake and reduces norepinephrine-induced lipolysis in rat retroperitoneal white adipose tissue. Lipids 47: 279-289.

SILVA FHSD ET AL. 2018. The antioxidant system in the soleus muscle of growing rats is stimulated by the administration of a low-protein/high-carbohydrate diet. Arch Physiol Biochem 29: 1-8.

SINGH S, DHINGRA S, RAMDATH DD, VASDEV S, GILL V AND SINGAL PK. 2010. Risk factors preceding type 2 diabetes and cardiomyopathy. J Cardiovasc Transl Res 3: 580-596.

SOKAL RR AND ROHLF FJ. 1995. Assumptions of analysis of variance. In: Sokal RR and Rohlf FJ (Eds), Biometry: The principles and practice of statistics in biological research. New York: WH Freeman and Co, p. 391-450.

TKAC I. 2005. Metabolic syndrome in relationship to type 2 diabetes and atherosclerosis. Diabetes Res Clin Pract 68: S2-S9.

STIRLING JL AND STOCK MJ. 1968. Metabolic origins of thermogenesis induced by diet. Nature 220: 801-802.

VALASSI E, SCACCHI M AND CAVAGNINI F. 2008. Neuroendocrine control of food intake. Nutr Metab Cardiovasc Dis 18: 158-168.

WHITAKER KW, TOTOKI K AND REYES TM. 2012. Metabolic adaptations to early life protein restriction differ by offspring sex and postweaning diet in the mouse. Nutr Metab Cardiovasc Dis 22(12): 1067-1074.

YAMAUCHI T ET AL. 2002. Adiponectin stimulates glucose utilization and fatty-acid oxidation by activating AMPactivated protein kinase. Nat Med 8(11): 1288-1295.

YAMAUCHI T ET AL. 2001. The fat-derived hormone adiponectin reverses insulin resistance associated with both lipoatrophy and obesity. Nat Med 7(8): 941-946.

\section{SUPPLEMENTARY MATERIAL}

Figure S1. 